\title{
Detection of enteroviral sequence in endomyocardial tissues from patients with cardiac diseases in Northern Brazil
}

\author{
Detecção de seqüências de enterovirus em tecido miocárdico \\ de pacientes com doenças cardíacas \\ no norte do Brasil \\ Mario de Lourdes C. Gomes, Helena Kopecka, Alberto Gomes Ferreira Jr, \\ Sheila Maria A. Gomes Ferreira, Luiz Alberto R. Maneschy \\ and Alexandre C. Linhares
}

\begin{abstract}
Resumo No presente trabalho, são mostrados resultados de um estudo piloto direcionado à detecção de seqüências de enterovirus em tecido cardíaco obtido a partir de biópsias endomiocárdicas de pacientes com doenças cardíacas na região Amazônica. Seis amostras coletadas de três pacientes foram analisadas por RT-PCR obtendo-se três espécimes positivos e três negativos. Esses achados preliminares sugerem a participação dos enterovirus na etiologia de doenças cardíacas, principalmente miocardites, e justificam estudos mais amplos nesse assunto.
\end{abstract}

Palavras-chaves: Doenças cardíacas. Enterovirus. RT-PCR.

\begin{abstract}
In the present report we describe the results from a pilot study aimed at detecting enterovirus sequence in cardiac tissues, obtained through endomyocardial biopsies, from patients suffering from cardiac diseases in the Amazon region. Six samples that were collected from three patients were analysed by RT-PCR showing 3 positive and 3 negative results. These preliminary findings suggest the participation of enteroviruses in the etiology of cardiac diseases, mainly myocarditis, and warrant further and broader local studies on this subject.
\end{abstract}

Key-words: Cardiac diseases. Enterovirus. RT-PCR.

\footnotetext{
Instituto Evandro Chagas, Fundação Nacional de Saúde; Fundação Luiz Décourt - Departamento de Cardiologia; Fundação Santa Casa de Misericórdia do Pará, Belém-Pará-Brazil and Molecular Virology Unit of Institut Pasteur, Paris, France.

Research supported by an agreement $n^{\circ}$ 022/ 97 between Fundo Estadual de Ciência e Tecnologia/ Secretaria de Estado de Ciência, Tecnologia e Meio Ambiente (FUNTEC/ SECTAM) and Fundação Luiz Décourt.

Address to: Dr ${ }^{a}$ Maria de Lourdes C. Gomes. Instituto Evandro Chagas. Av. Almirante Barroso 492, 66090-000 Belém, PA, Brasil. Fax: (091) 226-1284.

Recebido para publicação em 15/10/97.
} 
Cardiac diseases, in particular myocarditis, are often associated with the Picornaviridae enterovirus (EV) Coxsackie B6. This association has been suggested by several authors 3718 after isolation of the virus from patients yielding positive, specific serology. The first studies suggesting this association were done using the classic methodology which includes isolation of the virus and serology 3718 . Detection of EV sequence in cardiac tissues, particularly myocardial cells, was reported in the following years 213 . In addition, other studies characterised the nucleotide sequence of the EV CB1 type ${ }^{10}$. Certainly those studies were greatly facilitated by the early description of the primary structure of the polioviruses ${ }^{14}$.

The genome of enteroviruses consists of one single-stranded, plus sense RNA molecule of 7.2 to $8.5 \mathrm{~kb}$. Besides of the conserved untranslated region (UTR) at the $5^{\prime}$ end , (600$1200 \mathrm{nt})$, there is a shorter untranslated region at the $3^{\prime}$ extremity ( $3^{\prime}$ UTR) (50-100nt) and a coding region for single polyprotein of 2100 to 2400 amino acids in the middle of the genome. Both ends of the genome are modified: the $5^{\prime}$ end by VPg (23 amino acids) and the $3^{\prime}$ end by poly $(A)^{4}$.

The conserved sequence of the EV genome has been currently used for PCR amplification of the majority of the EVs. More recently, other sequences derive from several human picornaviruses have been used as probes for diagnostic purposes. The utilization of these probes for in situ hybridization 21 and gene amplification by the PCR9 112023 has helped to elucidate the etiology of myocardites. More recently, Hyypiä8 analysed samples from 276 myocardites and cardiomyopathy patients and detected enterovirus RNA in 56 myocardial biopsies and explanted hearts, using dot blot, in situ hibridization and PCR methods. The association between the viral infection and cardiomyopathies 19 appears to be confirmed by the presence of the EV genome in persistently infected patients 23 . These findings have suggested the possibility of the EV infection being relateg to the dilated cardiomyopathy 116 .

Experimental studies that have been conducted to detect EV sequences in cardiac tissues 121517 have used generic and specific primers22.

In Brazil, studies on the association between EV and cardiac diseases are scarce and were based so far on the use of viral, isolation and serologic studies 5 . This study was undertaken to detect $E V$ in cardiac biopsies from patients who live in northern Brazil, using virological molecular procedures.

Patients. The clinical and laboratory features of the patients studied are described as follows. The common finding in all of them was the abrupt onset of the cardiac disease. Patient 1 was a 35-year old black woman with history of fatigue starting at the $25^{\text {th }}$ day of puerperium. She presented with congestive heart failure due to peripartum cardiomyopathy characterized as class III according to The New York Heart Association. When she was admitted to the cardiology ward, the ECG showed sinus rhythm, heart rate of $98 \mathrm{bpm}$, left atrium enlargement, isolated ventricular premature beats and diffuse T-wave changes. Chest $\mathrm{X}$-ray showed bilateral pulmonary congestion and moderate left ventricle enlargement. Patient 2, a 28-year old black woman, presented with syncope, fatigue and palpitations. The ECG showed sinus rhythm and frequent ventricular prematures beats. Patient 3, a 74-year old white man, was admitted because of congestive heart failure due to dilated cardiomyopathy of recent onset characterized as class IV on the basis of The New York Heart Association. The ECG showed left bundle branch blockage. The chest X-ray showed pulmonary congestion and severe enlargement of the cardiac area. It should be pointed out that endomyocardial biopsies were done only when strictly indicated by cardiologists. In these cases, patients were fully informed on the procedure and written consents were routinely obtained from them.

PCR. The methodology was essentially the same used in previous studies 119 23. Two endomyocardial biopsy fragments were taken from the left ventricle by the myocardial bioptomes and kept on $-70^{\circ} \mathrm{C}$ or in formalin until they were analysed. Control samples were obtained at autopsy from patients with noncardiac diseases (belonging to the Unit of Molecular Virology of Pasteur Institut) The first procedure consisted of RNA extraction: the samples were homogenised in RNAzol (guanidium/phenol) and chloroform. Extracted RNA was precipitated with isopropanol, centrifuged, washed in ethanol and vacuum dried. The pellet was dissolved in sterile water and reprecipitated by ethanol in presence of $\mathrm{NaCl}$ and kept at $-20^{\circ} \mathrm{C}$ overnight. After a new centrifugation, the pellet was vacuum dried, dissolved in sterile water and submitted to RT-PCR assays. Initially the cDNA synthesis and the first PCR were performed in the same 
reaction: $3 \mu$ l of the extracted RNA and $47 \mu \mathrm{l}$ of the assay mixture were used. This was composed of transcription buffer $(250 \mathrm{mM}$ Tris- $\mathrm{HCl}, \mathrm{pH} 8.4$, $50 \mathrm{mM} \mathrm{MgCl} 2,350 \mathrm{mM} \mathrm{KCl}, 15 \mathrm{mM}$ dithiothreitol), RNAsin (40U), dNTPs mix (2mM), reverse transcriptase AMV (10U), primer 2, primer 3 (10pmole each), Taq polymerase (2.5U) and water. DNA amplification was carried out in a Cyclogene thermocycler $\mathrm{PCH}-3$ for 30 cycles (denaturation $94^{\circ} \mathrm{C}$, one min.; annealing $42^{\circ} \mathrm{C}$, one min.; extension $60^{\circ} \mathrm{C}$, one min.). In the second PCR were used $3 \mu$ l of the product from the first PCR and $97 \mu \mathrm{l}$ of the reaction mixture: Taq buffer, dNTP, primer 2, primer 10, Taq polymerase and water. The amplification products were analyzed by electrophoresis in $2 \%$ agarose gel and visualized by ethidium bromide staining (Figure 1).

Primers used. The primers used in this study were chosen in the 5 'non coding region of poliovirus type 1 according to the follow sequence: primer 2: 5'-CAAGCACTTCTGTTTCCCCGG-3'; primer 3: 5'-ATTGTCACCATAAGCAGCCA-3'; primer 10: 5'-ACGGACACCCAAAGTAGTCG-3'.

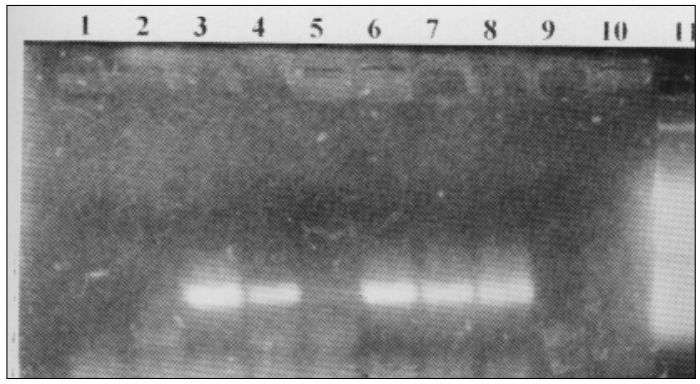

Figure 1 - RT-PCR amplification of EV nucleotide sequences from biopsies samples taken from cardiac patients inhabiting the Amazon region.

Lane 1, 2 and 3: samples stored at $-70^{\circ} \mathrm{C}$

Lane 4, 5 and 6: samples stored in formalin

Lane 7 and 8: positive control

Lane 9 and 10: negative control

Lane 11: molecular weight markers

Lane 1 and 4: patient 1, inconclusive

Lane 2 and 5: patient 2, negative

Lane 3 and 6: patient 3, positive

Of the three studied cases, one was positive (patient 3), one negative (patient 2) and one gave inconclusive results (patient 1) (i. e. the fragment stored in formalin was positive while that stored at $-70^{\circ} \mathrm{C}$ was negative). Although a few number of specimens have been examined, the detection of EV sequences in the formalinfixed sample rather than in that stored at $-70^{\circ} \mathrm{C}$, may indicate the former storage procedure as being suitable for studies like ours. Another possible explanation for this would be the uneven distribution of the viral genome in the myocardial tissue. The demonstration of enterovirus sequence in myocardial biopsies taken from some patients suffering from cardiomyopathy suggests the possibility of Coxsackie B virus being associated to its pathogenesis. Although preliminary, these results lead us to postulate that the EVs can be associated with the cardiomyopathies in northern of Brazil and warrant further and broader investigations on the occurrence of cardiomyopathies of possible viral aetiology in this region

\section{REFERENCES}

1. Andreoletti L, Hober D, Decoene C, Copin M-C, Lobert P-E, Dewilde A, Stankowiac C, Wattre P. Detection of enteroviral RNA by polymerase chain reaction in endomyocardial tissue of patients With chronic cardiac diseases. Journal of Medical Virology 48:53-59, 1996.

2. Bowles NE, Olsen EGJ, Richardson PJ, Archard LC. Detection of Coxsackie-B-virus-specific RNA sequences in myocardial biopsy samples from patients with myocarditis and dilated cardiomyopathy. The Lancet 1:1121-1123, 1986.

3. Burch GE, Sun SC, Chu K-C, Sohal RS, Colcolough HI. Interstitial and Coxsackievirus B Myocarditis in Infants and Children. The Journal of the American Medical Association 203:55-62, 1968.

4. Cann AJ. Principles of Molecular Virology. Academic Press Limited, London, 1995.

5. Ferreira Jr AG, Ferreira SMAG, Gomes MLC, Maneschi LA, Linhares AC. Enteroviruses as a possible cause of myocarditis, pericarditis and dilated cardiomyopathy in Belém, Brazil. Brazilian Journal of Medical and Biological Research 28:869-874, 1995.

6. Grandien M, Forsgren M, Ehrnst A. Enteroviruses. In: Lennete EH, Lennette DA, Lennette ET (eds) Diagnostic procedures for viral, rickettsial and chlamydial infections. $7^{\text {th }}$ Edition, American Public Health Association, Washington, p. 279-297, 1965.

7. Grist NR, Bell EJ. A six-year study of coxsackievirus $B$ infection in heart disease. Journal of Hygiene 73:165-172, 1974.

8. Hyypiä T. Etiological diagnosis of viral heart disease. Scandinavian Journal of Infectious Diseases 88 (suppl):25-31, 1993. 
9. Hyypiä T, Auvinen P, Maaronen M. Polymerase chain reaction for human picornaviruses. Journal of General Virology 70:3261-3268, 1989.

10. lizuka N, Kuge S, Nomoto A. Complete nucleotide sequence of the genome of coxsackievirus B1 Virology 156:64-73, 1987.

11. Jin O, Sole MJ, Butary JW, Chia WK, Mc Laughlin PR, Liu P, Liew CC. Detection of enterovirus RNA in myocardial biopsies from patients with myocarditis and cardiomyopathy using gene amplification by polymerase chain reaction. Circulation 82:8-16, 1990.

12. Kallajoki M, Kalino $H$, Wesslén L, Auvinen P, Hyypiä $\mathrm{T}$. in situ detection of enterovirus genomes in mouse myocardial tissue by ribonucleic acid probes. Laboratory Investigation 63:669-675, 1990.

13. Kandolf $R$, Ameis $D$, Kirschner $P$, Canu A, Hofschneider $\mathrm{PH}$. In situ detection of enteroviral genomes in myocardial cells by nucleic acid hybridization: an approach to the diagnosis of viral heart disease. Proceedings of the National Academy of Sciences of the United States of America 84:62726276, 1987.

14. Kitamura N, Semler BL, Rothberg PG, Larsen GR, Adler CJ, Dorner AJ, Emini EA, Hanecak R, Lee JJ, Van der Werf S, Anderson CW, Wimmer E. Primary structure, gene organization and polypeptide expression of poliovirus RNA. Nature (London) 291:547-553, 1981.

15. Klingel K, Hohenadl C, Canu A, Albrecht M, Seemann M, Mall G, Kandolf R. Ongoing enterovirusinduced myocarditis is associated with persistent heart muscle infection: quantitative analysis of virus replication, tissue damage, and inflammation. Proceedings of the National Academy of Sciences of the United States of America 89:314-318, 1992.
16. Kopecka H, Bouhour JB, Langlard JM, Petitjean J, Freymuth F. Entérovirus et cardiomyopathies dilatées. Pathologie Biologie 41:521-523, 1993.

17. Leparc I, Fuchs F, Kopecka H, Aymard M. Use of the polymerase chain reaction with a murine model of picornavirus-induced myocarditis. Journal of Clinical Microbiology 31:2890-2894, 1993.

18. Paul F M, Yin-Murphy M. Coxsackievirus B infections in children with myocarditis. Singapore Medical Journal 22:314-322, 1981.

19. Petitjean J, Kopecka H, Freymuth F, Langlard JM, Scanu P, Galateau F, Bouhour JB, Ferrière M, Charbonneau $P$, Komajda M. Detection of enteroviruses in endomyocardial biopsy by molecular approach. Journal of Medical Virology 37:76-82, 1992.

20. Rotbart HA. Enzymatic RNA amplification of the enteroviruses. Journal of Clinical Microbiology 28:438-442, 1990.

21. Tracy S, Chapman NM, McManus BM, Pallansch MA, Beck MA, Carstens J. A molecular and serologic evaluation of enteroviral involvement in human myocarditis. Journal of Molecular and Cellular Cardiology 22:403-414, 1990.

22. Weiss LM, Movahed LA, Billingham ME, Cleary ML. Detection of coxsackievirus B3 RNA in myocardial tissues by the polymerase chain reaction. American Journal of Pathology 138:497-503, 1991.

23. Zoll GJ, Melchers WJG, Kopecka H, Jambroes G, Poel van der HJA, Galama JMD. General primermediated polymerase chain reaction for detection of enteroviruses application for diagnostic positive and persistent infections. Journal of Clinical Microbiology 30:160-165, 1992. 